\title{
Rapid change of a cohort of 570 unproven stem cell clinics in the USA over 3 years
}

\author{
Paul S Knoepfler*,1,2 (iD \\ ${ }^{1}$ Department of Cell Biology \& Human Anatomy, University of California Davis, Davis, CA 95616, USA \\ ${ }^{2}$ Institute of Pediatric Regenerative Medicine, Shriners Hospital for Children Northern California, Sacramento, CA 95817, USA \\ *Author for correspondence: knoepfler@ucdavis.edu
}

\begin{abstract}
Aim: The industry of unproven stem cell clinics has rapidly mushroomed throughout the USA, posing risks to patients and the research field. In this study, the aim was to better define how this industry changes. Methods: I analyzed a large cohort of US stem cell clinic firms and their distinct clinic locations as defined in 2015-2016 for their status now in 2019. Results: About a quarter of the firms no longer marketed stem cells. Some lacked active websites, while others dropped stem cell services. Even so, the total number of clinics in this group increased because some firms greatly expanded their clinic numbers. Conclusion: Overall, the unproven clinic industry is a moving target requiring ongoing study and regulatory oversight.
\end{abstract}

First draft submitted: 17 May 2019; Accepted for publication: 10 July 2019; Published online: 28 August 2019

Keywords: bioethics $\bullet$ FDA $\bullet$ regenerative medicine $\bullet$ stem cell clinics

Stem cell and regenerative medicine research is making steady progress from the bench to the bedside [1]. Along with this growth and progress, specific challenges have emerged. For example, it is still relatively rare for universities or large teaching hospitals to offer physician training specifically in stem cells and regenerative medicine outside the standard hematology/oncology residency training programs, although the need for such programs has been recognized for at least a half a dozen years [2]. There are also additional sometimes difficult hurdles related to benchto-bedside translation [3]. Hype has been a persistent problem across most elements of the stem cell ecosystem as well [4].

Unfortunately, at the same time as legitimate clinical and translational research has advanced in this arena over the past decade working with the US FDA, in parallel the industry of so-called 'stem cell clinics' marketing unproven and non-FDA-approved offerings directly to consumers has also vastly increased, arguably representing one of the top challenges to the field. In 2015-2016, there were 351 unproven stem cell clinic firms documented in the USA advertising on the internet, collectively operating 570 clinic locations [5]. This cohort was the first reported comprehensive analysis of US stem cell firms and clinics based on systematic data collection. A roughly contemporaneous analysis of clinics more globally by Berger and colleagues found a similar problem both inside and outside the USA [6]. Strikingly, the Berger study found that the USA is the top global destination for stem cell clinic firms in terms of locations. The clinic problem has continued to worsen as the number of unproven stem cell clinics in the USA reportedly had increased by 2017 to approximately 715 [7]. Yet less than a decade earlier in 2008, there were no such American clinics identified that were advertising on the internet [8], indicating this is a relatively new phenomenon.

Adverse events have also been reported along with the rise of the stem cell clinic industry [9], but it is presently unknown if these are increasing in incidence, at least in part because some firms fail to voluntarily track and accurately report negative outcomes. There is nonetheless the perception that adverse events are increasing in number at least in part driven by numerous recent cases of infections from unproven stem cell infusions [10,11]. Variable quality of stem cell production laboratories is likely a factor increasing the risk of adverse events, but so too is the unfortunate reality that many of those administering stem cells to patients are not even physicians or if they are physicians they frequently are practicing outside of their areas of expertise [12,13].

Future Medicine 
'Unproven' stem cell clinics are defined for the purpose of this paper as those marketing non-FDA approved, purported stem cell-related offerings in a context that is clearly distinguishable from traditional FDA IND-cleared clinical trials. For example, unproven clinics almost universally charge large fees, while traditional clinical trials mostly do not charge patients. Clinics often also do not conduct preclinical trials in animals. However, 'unproven' does not necessarily always equate with noncompliant with FDA guidances or regulations. The use of the term 'clinics' here is not meant to imply that the firms actually offer anything of medical benefit.

Despite widespread media coverage of patient harms linked to unproven clinics including lost vision, it is thought that many patients still are clinic customers each year [14]. Specific unproven stem clinics use a variety of strategies to attract potential customers including web-based marketing [15], mainstream media advertising [16], fake news [17,18], on-line fundraising [19], patient video testimonials [20] and 'infomercial' seminars [21]. Some also try to gain an air of legitimacy such as by getting listed on the Clinicaltrials.gov website [22], falsely listing affiliations with academic scientists, or claiming FDA approval or compliance [23]. Overall, these clinic marketing efforts not only pose health risks to consumers but also muddy the waters as to public understanding of and support for stem cell and regenerative medicine research. Given the lack of randomized controlled trial data on unproven clinic interventions, it remains unclear if some clinics can offer patients any real benefits and the extent of risks those patients may face.

At the same time, federal and state regulators have struggled to keep up with the rapid changes in the unproven stem cell clinic industry as it ballooned from 2009 to 2016. Regulators such as the FDA face the difficult task of balancing efforts at facilitating legitimate, innovative clinical research by good citizens of the stem cell field such as via the FDA Regenerative Medicine Advanced Therapy (RMAT) Designation program, while at the same time taking proportionate oversight disciplinary actions against noncompliant parties including unproven clinics [24].

From 2016 to 2019, some key events may have sparked additional rapid changes, in some cases involving increased regulatory oversight activities that may tend to put a damper on the unproven clinic industry longer term. For instance, in 2018 the FDA sued in two federal district courts for permanent injunctions against multiple firms, including a network of approximately 100 clinics headquartered in California called Cell Surgical Network [25]. While the California district court case is still pending, the FDA prevailed in the Florida case leading to a permanent injunction against the unproven stem cell clinic firm US Stem Cell, Inc. related to noncompliant use of adipose stem cell preparations. There is also greater awareness of adverse events among clinic patients [9]. In addition, there have been more civil lawsuits by patients against clinics [26]; and in 2019, the New York State Attorney General filed suit against a clinic firm in that state [27]. While these kinds of events are hypothesized to discourage the unproven stem cell clinic industry, the nature of recent change in this industry is not well understood in part because data have not been published tracking the same group of clinics over time. To address this gap, here I have revisited the 2015-2016 cohort of 351 firms and 570 clinics, analyzing where they stand in early 2019, generally finding a high rate of change within it including approximately one quarter of all firms becoming inactive in terms of stem cell marketing, but other firms greatly expanded leading to a small net increase in clinic numbers for the group.

\section{Methods}

I visited every firm's website from the 2015 to 2016 cohort and collected new data starting in March 2019: firm website status (active, still same firm), still marketing stem cells or not, and the number of clinic locations. The supplemental information of the Turner and Knoepfler article published in 2016 examining the US marketplace for direct-to-consumer advertising of stem cell interventions was used as the source of the websites [5]. This database was chosen, rather than a newer one, to allow for a sufficient period of time from initial documentation of clinics to observe changes in their status over time.

Apparently inactive websites in March 2019 were visited a second time that same month and then a third time in June 2019 to confirm their inactive status. Furthermore, an independent internet search for these specific putative inactive firms was then conducted searching by firm name, capturing a few firms that still exist by the same name as unproven stem cell providers but that have changed their website URLs.

Firms with active websites but that did not appear to still market stem cells based on their website homepage, were analyzed further by looking at other pages on the site including, in particular, the 'Services' page. Only then, if evidence of stem cell marketing was still not found, were the sites deemed to have stopped marketing stem cells. Searches for the same clinic providers but at a different clinic/firm were generally not undertaken due to the complexity of such efforts. The dataset on the firms and their individual clinic locations from 2015 to 2016 was then compared to the 2019 data. To be clear, this study was not designed to capture data on entirely new clinics. 


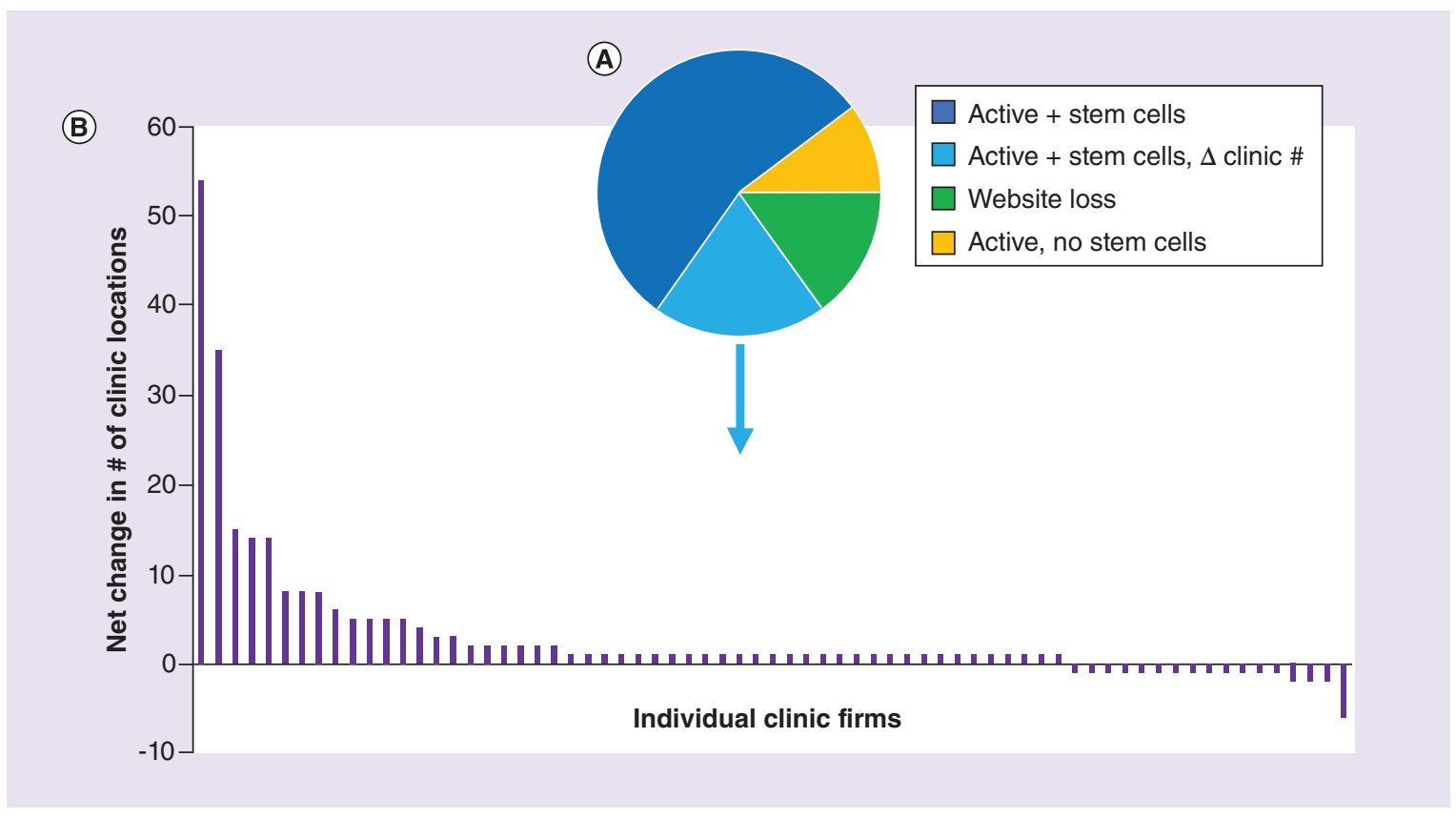

Figure 1. Changes in the stem cell clinic cohort from 2015-2016 to 2019. (A) Characteristics of 2015-2016 cohort now in 2019. The yellow parts of the pie chart are those clinic firms that are still active as businesses, but which do not clearly market stem cells anymore. The green portion represents those clinics without an active website at the time of the study. The two blue portions of the pie chart are clinics that still actively sell stem cells, and within this group the lighter blue subset represents those that have changed their number of clinic locations. (B) Chart of the distribution of increases or decreases in stem cell clinics per individual firm among the subset that had changes (the light blue wedge of the pie chart above). Note that the assessment of clinic number changes in one specific clinic firm, R3 Stem Cell, was not possible in 2019 because it was a network of multiple clinics (but an unknown number) in 2016 but was listed as one in that original dataset. Also, R3 Stem Cell's network includes some clinics listed separately in the database. Thus, I listed this firm as having one clinic again in 2019 for consistency.

\section{Results}

As of March-June 2019, 52 (approximately 15\%) of the 2015-2016 cohort of unproven stem cell clinic firms no longer had active websites and may have shut down. These firms were not identifiable at another website going by the same firm name as analyzed by the separate Internet search in June. Another 36 firms (10\%), while still in business as the same firm, appeared to no longer market stem cells as determined in searches in March and June. Thus, strikingly in total 88 or about a quarter of the 2015-2016 clinic firms have changed such that they no longer clearly market stem cells on the web just 3 years later (Figure 1). This trend of firms potentially leaving this marketplace may be related to recent clarification of relevant FDA guidances and more enforcement actions such as lawsuits, but could also be connected to increased activity at the state level or unrelated economic forces. Of those firms that now no longer have active websites clearly operating as the same businesses marketing stem cells, most based on absolute numbers were located in Florida, Texas, California, and Arizona, with this observation likely simply due to the fact that these states have the most clinics overall. Of the 263 active stem cell clinic firms still marketing stem cells, five had changed primary web addresses but appeared to be the same company, suggesting a surprisingly low prevalence of moves to exclusively new web addresses by clinic firms over the 3 -year period. It is possible that some firms use multiple web addresses, however.

Of the 263 clinic firms still marketing stem cells under their original firm name, 69 (26\%) had changed their number of listed clinic locations from 2016 to 2019 (Figure 1), mostly upward. The mean number of locations per active firm increased by $43 \%$ (from 1.6 to approximately 2.3 clinics/firm). Decreases in clinic numbers by firms were somewhat rarer and of smaller magnitude.

Despite a quarter of clinic firms becoming inactive from 2016 to 2019, surprisingly the total number of clinic locations just in this cohort went up from 570 to $610(+7 \%)$ during this same period. This net increase was mainly driven by eight firms with relatively large increases in clinic locations they listed on their websites. 
While there was no strong association of the individual type of stem cell marketed with whether firms tended to become inactive or expand, specific stem cell clinic brands exhibited some interesting changes. Searching by brand, of the 42 Cell Surgical Network affiliated firms (they generally use adipose stromal vascular fraction, which the FDA has defined as a drug product) in the original 2015-2016 published database, a third (14) apparently were no longer actively marketing stem cells in 2019 during the period of analysis. Of these 14, three were still active as businesses or as the same physician but did not appear to market stem cells while the other 11 had inactive websites. The other major stem cell clinic brand identified, Regenexx, which primarily markets what appear to be generally FDA-compliant bone marrow-related offerings for orthopedic conditions, had 24 firms listed in the 2015-2016 database. As of 2019 five of these had inactive websites, although one of these, Harborview Medical, appears to have merged with the larger Regenexx corporation.

\section{Discussion}

Here, I report that the unproven stem cell clinic industry as represented by the published 2015-2016 cohort is a rapidly changing entity. Taken together, the data from this new 2019 study are both encouraging and disheartening. The apparent closing or inactivity of many clinic firms over just a 3-year period might suggest a positive trend sparked by more oversight activity in part due to advocacy efforts to pressure agencies such as the FDA to do more, but tempering that interpretation is the reality that many firms continue with business as usual and some appear to have dramatically expanded geographically. Furthermore, there is other evidence in the field that the stem cell clinic industry as a whole has continued to grow, which is concerning. The observation of more clinics per firm on average likely translates to more patients being put at risk, although this possibility is difficult to test given that clinic firms do not typically release data on their patient populations. At the same time, if clinics in general are more concentrated within fewer ownership firms, this may make enforcement by the FDA and other agencies at least somewhat easier. It is also possible that small medical clinics in a general sense including those having nothing to do with stem cells have a relatively high turnover rate. Without further study, it is not entirely clear if stem cell clinics have a disproportionately higher turnover rate, although that is likely.

It is also important to note that a limitation of this study is that it was conducted online only with the exception of a few phone calls to clinic firms to clarify their offerings or overall status. The inherently rapidly changing nature of the Internet means that the data captured in March-June 2019 just represent one snapshot. Websites can change even from day to day, and I predict that this cohort of stem cell clinics will continue to rapidly evolve. Other potential limitations include that there may be multiple websites per clinic firm, overlapping networks of clinics, and cross-ownership at work, making it difficult to be completely sure about the precise relationship between the number of unique firms and the number of unique clinics. Within one multi-clinic firm, it is also possible that not every clinic location listed actively injects patients with stem cells. Another level of complexity is that some operators of specific apparently inactive clinic firms may have moved on to start new clinic firms (a phenomenon captured in a few cases during this study), rather than abandoning marketing of unproven, non-FDA-approved stem cells.

The fact that a quarter of firms may have exited the unproven stem cell market during just a 3-year period, while encouraging, also clarifies a potentially difficult challenge facing regulators. If regulators take years to act, those individuals responsible for running many noncompliant clinic firms posing serious risks may be hard to locate and be held responsible if the previous incarnation of the firm is gone. Furthermore, as noted earlier these clinic operators may proceed to start entirely new unproven clinic firms posing risks to patients. In such scenarios, regulators may have a harder time reining in consistently problematic actors and protecting patients unless oversight takes place at a more rapid rate.

\section{Conclusion}

The current study suggests the clinic industry is a moving target, which needs to be carefully monitored based on continuous data collection and analysis to guide appropriate oversight. The stem cell research community should continue to actively study and work to reduce both the size of the unproven clinic industry and the risks it poses to the overall stem cell ecosystem including to patients and the stem cell research field [28]. 


\section{Summary points}

- The unproven stem cell clinic field is rapidly expanding, but the nature of change within it is poorly understood.

- In 2015-2016, a primary database was established documenting key information about US stem cell clinic firms.

- Using this database as a starting point, the current study examined how this cohort of unproven stem cell clinics and their clinic locations changed over a 3-year period.

- I found that about a quarter of stem cell clinic firms appeared to no longer marketed stem cells. These firms no longer selling stem cells via their original firm names included firms with inactive websites and also others that were still active as companies, but no longer clearly offered stem cells.

- Nonetheless, the total number of clinic locations operating within this cohort moderately increased in part due to apparent large expansions of clinic numbers by a handful of firms.

- Overall, this study highlights the instability and rapid change in the unproven stem cell clinic industry, arguing for careful monitoring of its development over time.

Financial \& competing interests disclosure

The author has no relevant affiliations or financial involvement with any organization or entity with a financial interest in or financial conflict with the subject matter or materials discussed in the manuscript. This includes employment, consultancies, honoraria, stock ownership or options, expert testimony, grants or patents received or pending, or royalties.

No writing assistance was utilized in the production of this manuscript.

\section{References}

1. Clarke G, Harley P, Hubber EL et al. Bench to bedside: current advances in regenerative medicine. Curr. Opin. Cell Biol. 55, 59-66 (2018).

2. Knoepfler PS. Call for fellowship programs in stem cell-based regenerative and cellular medicine: new stem cell training is essential for physicians. Regen. Med. 8(2), 223-225 (2013).

3. Dimmeler S, Ding S, Rando TA, Trounson A. Translational strategies and challenges in regenerative medicine. Nat. Med. 20(8), 814-821 (2014).

4. Caulfield T, Sipp D, Murry CE, Daley GQ, Kimmelman J. Scientific Community. Confronting stem cell hype. Science 352(6287), 776-777 (2016).

5. Turner L, Knoepfler P. Selling stem cells in the USA: assessing the direct-to-consumer industry. Cell Stem Cell 19(2), 154-157 (2016).

6. Berger I, Ahmad A, Bansal A, Kapoor T, Sipp D, Rasko JEJ. Global distribution of businesses marketing stem cell-based interventions. Cell Stem Cell 19(2), 158-162 (2016).

7. Turner L. The US direct-to-consumer marketplace for autologous stem cell interventions. Perspect. Biol. Med. 61(1), 7-24 (2018).

8. Knoepfler PS, Turner LG. The FDA and the US direct-to-consumer marketplace for stem cell interventions: a temporal analysis. Regen. Med. 13(1), 19-27 (2018).

9. Bauer G, Elsallab M, Abou-El-Enein M. Concise review: a comprehensive analysis of reported adverse events in patients receiving unproven stem cell-based interventions. Stem Cells Transl. Med. 7(9), 676-685 (2018).

10. Olmedo-Reneaum A, Garcia-Juarez I, Toapanta-Yanchapaxi L et al. Rogue 'stem cell clinic' leads to Mycobacterium abscessus infection. Lancet 393(10174), 918 (2019).

11. Cdc. Notes from the field: infections after receipt of bacterially contaminated umbilical cord blood-derived stem cell products for other than hematopoietic or immunologic reconstitution - United States, 2018 (2018). https://www.cdc.gov/mmwr/volumes/67/wr/pdfs/mm6750a5-H.pdf

12. Fu W, Smith C, Turner L, Fojtik J, Pacyna JE, Master Z. Characteristics and scope of training of clinicians participating in the US direct-to-consumer marketplace for unproven stem cell interventions. JAMA 321(24), 2463-2464 (2019).

13. Knoepfler P. Top 10 ways non-compliant stem cell clinic docs jeopardize their careers. Niche(2015). https://ipscell.com/2015/03/stemcellclinicdocs/

14. Knoepfler P. Negative stem cell clinic outcomes in the U.S. include 3 blinded women. Niche(2019). https://ipscell.com/2016/09/negative-stem-cell-clinic-outcomes-include-3-blinded-women/

15. Murdoch B, Zarzeczny A, Caulfield T. Exploiting science? A systematic analysis of complementary and alternative medicine clinic websites' marketing of stem cell therapies. BMJ Open 8(2), e019414 (2018).

16. Knoepfler P. Money talks: stem cell clinic ads mushrooming in mainstream medi. Niche(2017). https:/ipscell.com/2017/07/money-talks-stem-cell-clinic-ads-mushrooming-in-mainstream-media/

17. Marcon AR, Murdoch B, Caulfield T. Fake news portrayals of stem cells and stem cell research. Regen. Med. 12(7), 765-775 (2017). 
18. Knoepfler P. Stem cell fake news driving biotech investors or vice versa. . . or what? Niche(2017). https://ipscell.com/2017/05/stem-cell-fake-news-driving-biotech-investors-or-vice-versa/

19. Snyder J, Turner L, Crooks VA. Crowdfunding for unproven stem cell-based interventions. JAMA 319(18), 1935-1936 (2018).

20. Hawke B, Przybylo AR, Paciulli D, Caulfield T, Zarzeczny A, Master Z. How to peddle hope: an analysis of youtube patient testimonials of unproven stem cell treatments. Stem Cell Rep. 12(6), 1186-1189 (2019).

21. Knoepfler PS. The stem cell hard sell: report from a clinic's patient recruitment seminar. Stem Cells Transl. Med. 6(1), 14-16 (2017).

22. Turner L. ClinicalTrials.gov, stem cells and 'pay-to-participate' clinical studies. Regen. Med. 12(6), 705-719 (2017).

23. Snyder J, Turner L. Selling stem cell 'treatments' as research: prospective customer perspectives from crowdfunding campaigns. Regen. Med. 13(4), 375-384 (2018).

24. Knoepfler PS. Too much carrot and not enough stick in new stem cell oversight trends. Cell Stem Cell 23(1), 18-20 (2018).

25. Knoepfler P. In historic step, FDA \& DOJ seek injunctions on 2 key unproven stem cell clinic firms. Niche (2018). https://ipscell.com/2018/05/in-historic-step-fda-doj-seek-injunctions-on-2-key-unproven-stem-cell-clinic-firms/

26. Horner C, Tenenbaum E, Sipp D, Master Z. Can civil lawsuits stem the tide of direct-to-consumer marketing of unproven stem cell interventions. NPJ Regen. Med. 3, 5 (2018).

27. Office NYaGS (2019). https://ag.ny.gov/sites/default/files/park_ave_stem_cell_clinic_complaint.pdf

28. Knoepfler PS. Mapping and driving the stem cell ecosystem. Regen. Med. 13(7), 845-858 (2018). 